husband's brother, Paolo. In referring to the story here Shaw employs a version of the title of Tchaikovsky's symphonic fantasy, Francesca da Rimini (1876).

2. William Jennings Bryan (1860-1925), a fiery and indefatigable orator, was an unsuccessful candidate for the American presidency on three occasions. His fundamentalist religious views led him to assist the prosecution in the famous Scopes trial of 1925, in which a schoolteacher was accused of teaching Darwinian evolutionary theories instead of divine creation.

3. In Shaw's early play, Mrs Warren's Profession, Mrs Warren is the owner of a chain of brothels.

4. Eugène Brieux (1858-1932), a French dramatist in the naturalist tradition whose social problem plays were much admired by Shaw.

\title{
Sex, Love and Marriage: III
}

From Hayden Church, 'Myself and Love. By G. Bernard Shaw in the Most Remarkable Interview He has Ever Given', Sunday Dispatch, 6 January 1929.

How great (or how small) a part has love played in the life of George Bernard Shaw? Before, at the age of forty-two, he surprised everybody by marrying, he was generally regarded as a misogynist. Some people persist in regarding him as something like that even now! Among these is one of the cleverest women of my acquaintance, and she, on hearing that I was to interview Mr Shaw, remarked: "The question I should most like to ask GBS is, "Have you ever been in love?" But I think,' she added, 'that I could answer it myself with one word: Never!'

I asked Shaw to say if she was right or wrong. His reply was:

'Your circle of female acquaintances must be an extraordinarily stupid one if the cleverest of them cannot guess. What does the question mean?

'A love-affair may mean anything from a correspondence continued for years between people who have hardly ever met, to one of those inevitable results of a drunken orgy which you described as characteristic of American girls under the spell of Prohibition.

'The truth is, all the cases worth counting are different. I could tell you that I have never been in love. I could tell you I have never been out of it. And you would be no wiser than you were before. Therefore I shall not tell you anything at all. Next question, please.' 